\title{
SELECTION OF AYRSHIR CATTLE OF THE VOLOGDA REGION FOR PRODUCTIVE LONGEVITY
}

\author{
Key words: ayrshire breed; breeding; bulls; useful lives; lifetime milk yield.
}

\section{Authors' personal details}

1. Litonina Anastasia, researcher, Vologda Scientific Center of the Russian Academy of Sciences, 160014, Vologda, Gorky Street, 56A, phone:+7 (8172) 59-78-25, e-mail: litoninaas@mail.ru.

2. Kudrin Alexandr, Doctor of Biological Sciences, Professor, the Chair of Zootechnics and Biology, Vereshchagin Vologda State Dairy Farming Academy, 160555, Vologda, Molochnoe, Shmidta Street, 2, phone: +7 (8172) 52-57-30, e-mail: kudrin230949@yandex.ru.

This article shows the impact of a birthplace of Ayrshire population producers of the Vologda area on a lifelong productivity and time periods of their daughters' usage at breeding factories Agrofirm «Krasnaya Zvezda» and Breeding Factory «Maiskii». The prolonged period of usage is typical for daughters of bulls from the Yaroslavl area 4 finished lactations, which is 38,9\% higher than average population values. More than 3 lactations are typical for daughters of producers, who were born in the Vologda area and Finland. The best yield results per single lactation $(9,738 \mathrm{~kg})$ are typical for daughters of the Leningrad selection bulls: the number is $11,9 \%$ higher than average population parameters. According to average yield of basic fatness per one yield day, the best groups are daughters of

(C) Литонина А.С., Кудрин А.Г. bulls from the Moscow and Leningrad areas: the indicator exceeds average values by $4,6 \%$. In order to increase longevity, it is advisable, on condition of improving feeding and maintenance systems, to use bulls from the Vologda and Yaroslavl areas in the selection. Producers from the Moscow and Leningrad areas increase a mass share of fat in population. The influence of bulls-producers on productive usage of daughters is stated. According to daughters' life expectancy parameter, we need to mention the following bulls: Slavnyi 1366, Admiral 10351, Zavitok 404, Air 15, and Zavet 13. According to yield of basic fatness per one yield day parameter, the best bulls' daughters are Kh'yumor 328, Khukko 173, Silach 1592, Kentavr 522, Aromat 111, Volan 106202505: the indicator was between $37,3 \mathrm{~kg}$ and $43 \mathrm{~kg}$.

УДК 638.144.52

DOI: $10.31563 / 1684-7628-2020-53-1-99-106$

Г.С. Мишуковская, М.Г. Гиниятуллин, Д.В. Шелехов, Е.А. Смольникова, А.И. Науразбаева

\section{ЭФФЕКТИВНОСТЬ ПРОБИОТИЧЕСКИХ КОРМОВЫХ ДОБАВОК ПРИ ОСЕННЕЙ ПОДКОРМКЕ ПЧЕЛИНЫХ СЕМЕЙ}

\section{Ключевые слова: медоносные пчелы; осенние подкормки; зимовка пчел; пробиотики; сила се- мей; печатный расплод.}

Введение. Осенние подкормки пчелиных семей предназначены для решения следующих задач: стимуляция яйцекладки маток, восполнение дефицита корма и профилактика болезней пчел. Ужесточение требований к качеству продукции пчеловодства, её экологической чистоте ограничивает возможность применения для профилактики заболеваний химиотерапевтических средств. В качестве альтернативы рассматривается возможность использования микробиологических препаратов, созданных на основе нормальной микрофлоры кишечника пчел для укрепления иммунной системы. Пробиотики ис- пользуют в разных отраслях животноводства для профилактики и лечения дисбактериозов, нормализации микрофлоры пищеварительного тракта после лечения антибиотиками или антибактериальными химиотерапевтическими средствами, стимуляции неспецифического иммунитета $[15,16]$. Ряд авторов отмечают повышение продуктивности при подкормке семей пчел сахарным сиропом, обогащенным культурами Lactobacillus salivarius и B. subtilis subtilis, и снижение титра поражения Nosema sp. и Varroa $s p$. по сравнению с контролем $[14,21]$. Отмечено также стимулирующее влияние пробиотиков на 
яйценоскость пчелиных маток и увеличение силы семей $[5,8,9]$. Имеются сведения об укреплении иммунитета пчел под действием пробиотических препаратов. Так, о повышении устойчивости пчел к P. larvae под воздействием пробиотиков свидетельствуют результаты исследований Daisley B.A. et al. [12]. Они выявили стимулирующее действие пробиотиков на экспрессию гена Defensin-1 - пептида, играющего ключевую роль в защите организма пчел против этой инфекции. По данным Arredondo D. et al. (2019), Lactobacillus kunkeei, выделенная из кишечника пчел, снижает смертность личинок, пораженных $P$. larvae, и количество спор $N$. ceranae у взрослых особей [7]. При подкормке сахарным сиропом с препаратом апиник, содержащим L. acidophilus и экстракт дрожжей Saccharomyces cerivisiae в кишечном тракте пчел, отмечено повышение значения уровня лактобактерий, снижение количества условно-патогенной микрофлоры, стафилококков, дрожжевых и плесневых грибов [4]. Использование этого препарата влияет на сохранность пчел и оптимальный расход корм в зимний период, способствует интенсивному наращиванию силы семей в период весеннего развития [1].

От состояния микробиоты кишечника зависит не только здоровье пчел, но и в целом благополучие пчелиной семьи $[10,20]$. На состав ее оказывают влияние различные факторы: источники корма (растения-медоносы), фитонциды растений, пестициды, лекарственные препараты, используемые в пчеловодстве. Подавляя развитие одних видов бактерий и стимулируя развитие других, эти факторы могут вносить определенный дисбаланс в функционирование кишечника. Для пчел характерны также и сезонные изменения в составе микрофлоры кишечника. Следствием недостатка корма и температурного стресса является снижение иммунитета пчел $[17,18]$. Кроме того, отсутствие у пчел возможности опорожнения толстой кишки в безоблетный период формирует фактор риска развития у них инфекционных заболеваний. Состояние микробоценоза у пчел, идущих в зиму, во многом определяет их выживаемость во время зимовки. В связи с этим целью наших исследований явилась оценка влияния осенней подкормки с использованием новых пробиотических кормовых добавок на качество зимовки пчелиных семей.

Материалы и методы. Исследования проводили в 2018-2019 гг. на учебно-опытной пасеке Башкирского государственного аграрного университета.

Влияние кормовых добавок на жизнедеятельность пчел определяли по их сохранности в садках в лабораторных условиях. Пчел суточного возраста, полученных из одной семьи с помощью сетчатого изолятора, заселяли в садки по 55 шт. в каждый. Садки делили на группы по 3 садка в каждой. Контрольная группа получала $60 \%$-ный сахарный сироп (СС), опытным давали сироп с кормовыми добавками: 1 и 2 опытные группы - пробиотики СпасиПчел и ПчелоНормосил в дозе 2 мл на 0,5 л сахарного сиропа.

Используемые в наших исследованиях пробиотические кормовые добавки разработаны ООО «НВП БашИнком». В состав кормовой добавки СпасиПчел входит 2 штамма бактерий $B a$ cillus subtilis. ПчелоНормосил содержит лактобактерии, бифидобактерии и пребиотик арабиногалактан (иммуномодулятор из хвои лиственницы сибирской).

С целью изучения влияния пробиотиков на качество зимовки сформировали 3 группы по 10 семей пчел в каждой группе. В первой декаде сентября 2018 г. проводили подкормку семей. В контрольной группе семьям давали чистый $60 \%$-ный сахарный сироп. Пчелам опытных групп скармливали сироп с кормовыми добавками: опытной 1 - СпасиПчел в дозе 2 мл на пчелиную семью, опытной 2 - ПчелоНормосил в такой же дозировке. Подкормку осуществляли с интервалами 3 дня по 0,5 л на пчелиную семью вечером, заливая в боковые кормушки. Учет состояния пчелиных семей после подкормки проводили дважды - осенью 2018 г. перед постановкой их в зимовник и в первой декаде апреля 2019 г. после выставки. В ходе учета определяли силу семей в улочках, количество печатного расплода в гнездах с помощью рамки-сетки со сторонами квадратов $5 \times 5$ см, вмещающих по 100 пчелиных ячеек. Расход корма рассчитывали по разности массы ульев до постановки в зимовник и после выставки.

Уровень развития жирового тела рабочих пчел оценивали по методике А. Маурицио [19]. Все полученные данные обработаны методами вариационной статистики.

Результаты исследований. Изучение влияния пробиотиков на продолжительность жизни пчел в садках в условиях лаборатории показало, что при добавлении к сахарному сиропу кормовой добавки СпасиПчел отход особей происходил медленнее, чем в контроле, и через две недели после начала эксперимента этот показатель составил $26 \%$ - на 12,2 \% меньше контрольного значения (рисунок 1). К концу опыта на 25-е сутки после начала подкормки в этой группе погибло лишь 50 \% пчел, на 27,8 \% меньше, чем в контроле. При использовании кормовой добавки ПчелоНормосил разность с контролем составила в эти сроки $9,7 \%$ и $10,4 \%$ соответственно. 


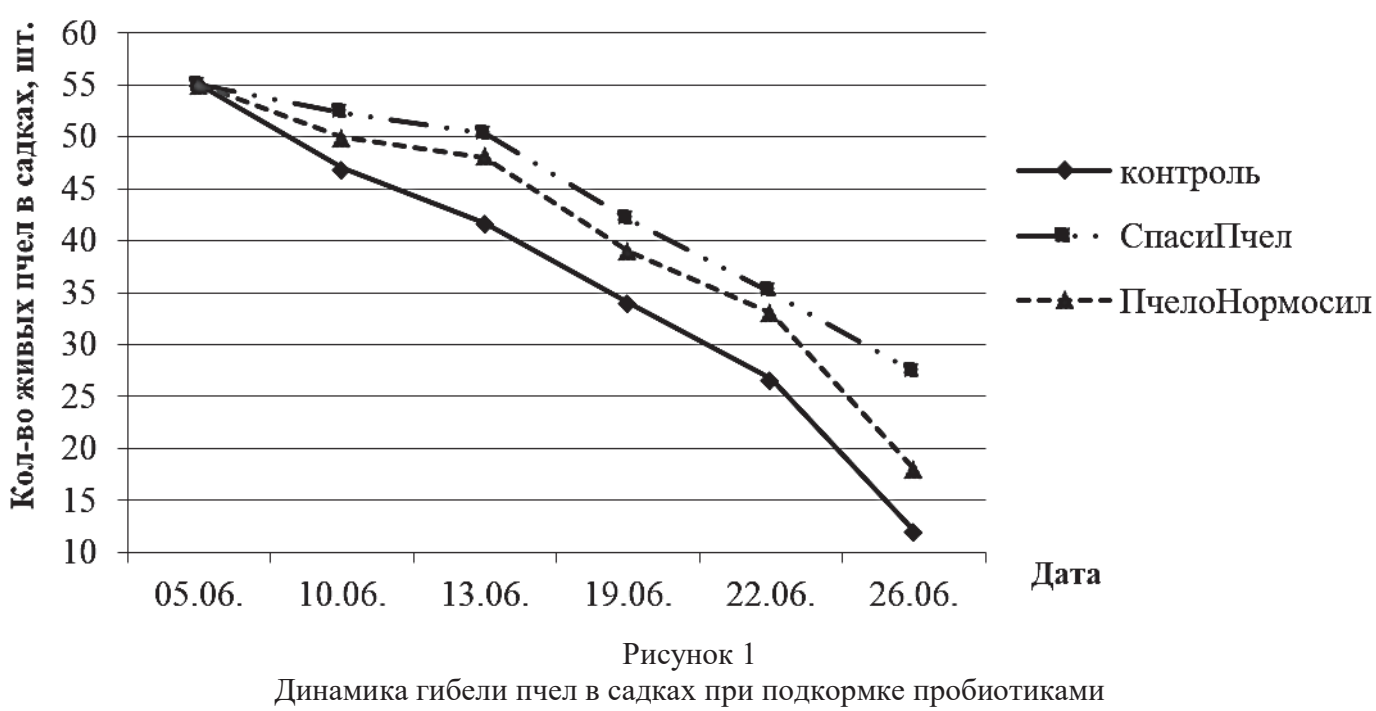

В контрольной группе продолжительность жизни пчел в садках составила в среднем 14,6 суток. В опытных группах этот показатель достоверно превышал контрольное значение в 1,2 раза (СпасиПчел) и 1,14 раза (Пчелонормосил). Расход корма на одну пчелу в сутки в этих группах был ниже контрольного значения в 1,4 и 1,1 раза соответственно.

Пасечные опыты по оценке эффективности осенней подкормки были заложены в начале сентября 2018 года. Для этого провели учет состояния пчелиных семей и сформировали опытные и контрольную группу. На начало опыта (до подкормки) пчелиные семьи имели силу от 8 до 10 улочек, соторамок в гнезде 8-11 шт., в том числе соторамок с расплодом - 4-6 шт., количество углеводного корма составляло 9-12 кг. В ноябре перед постановкой пчел в зимовник вновь провели взвешивание ульев и осмотр пчелиных семей. Во всех семьях наблюдали значительное сокращение силы после отхода летних пчел. Наибольший показатель силы при этом был зарегистрирован в семьях 1-й опытной группы, он превосходил контрольное значение на $24 \%$. Семьи 2-й опытной группы по силе на $20 \%$ уступали контролю.

Оценка степени развития жирового тела пчел также показала лучшие результаты в 1-й опытной группе (рисунок 2). У пчел этой группы уровень развития жирового тела был больше в среднем на $25,4 \%$, чем у пчел контрольной группы, во 2-й опытной - выше на 17,5 \%. Повторная оценка, проведенная в декабре 2018 года, подтвердила данные об увеличении степени развития этого органа у пчел опытных групп, хотя разность с контролем была несколько ниже - $19 \%$ и 9,1 \% соответственно.

Таким образом, использование пробиотика СпасиПчел в осенней подкормке оказало положительное влияние на подготовку семей пчел к зимовке. Рабочие пчелы 1-й опытной группы накопили больше запасных питательных веществ в теле, а семьи в целом ушли в зиму более сильными. Во второй половине ноября ульи с пчелами занесли в полуподземный зимовник. В течение всего периода зимовки температуру воздуха в зимовнике поддерживали в пределах $0 \pm 5^{\circ} \mathrm{C}$, относительную влажность на уровне $70-85 \%$. Выставку пчелиных семей из зимовника весной 2019 года осуществили в начале апреля. После выставки провели взвешивание ульев и осмотр пчелиных семей. В контрольной группе гнездо одной пчелиной семьи за период зимовки было сильно опоношено, в ней отсутствовала матка. Сила семьи составила одну улочку. В связи с этим она была объединена с другой в пределах группы. В 1-й опытной группе отмечена гибель одной пчелиной семьи из-за недостатка корма в зоне расположения зимнего клуба пчел. Во 2-й опытной группе в одной семье отсутствовала матка, в связи с чем семья была объединена с другой семьей из этой группы. Таким образом, в каждой группе после зимовки потеряно по одной семье пчел.

Сила семей контрольной группы после выставки из зимовника составила 5,0 улочек (рисунок 3). Семьи 1-й опытной группы по этому показателю превосходили контроль на 21,3%, 2-й опытной - уступали на $14,9 \%$.

Максимальное количество подмора в гнездах пчел выявлено в 1-й опытной группе, что можно объяснить большим количеством особей в этих семьях. Минимальное - во 2-й опытной (таблица 1). По показателю расхода корма за период зимовки из расчета на одну пчелиную семью в 1-й опытной группе заметных различий с контролем не выявлено. Во 2-й опытной он был меньше контрольного значения на 1,5 кг (на $22,1 \%)$. Из расчета на 1 улочку пчел меньше всего корма за период зимовки израсходовали семьи, получавшие в осенней подкормке пробиотик СпасиПчел - на 0,31 кг (22,0 \%) меньше, 
чем контрольные семьи. Во 2-й опытной группе (ПчелоНормосил) разность с контролем по этому показателю составила 0,14 кг (9,9\%).

Наиболее объективным показателем качества зимовки является количество выращиваемого расплода в пчелиной семье в весенний период. По данным учета, после выставки из зи- мовника количество печатного расплода в контрольной группе в среднем составило 61,3 сотен ячеек. Максимальный показатель, зарегистрированный в семьях, получавших с подкормкой пробиотик СпасиПчел, - на 58,7 \% выше контрольного значения. В семьях, получавших пробиотик ПчелоНормосил, он был выше на 23,5%.

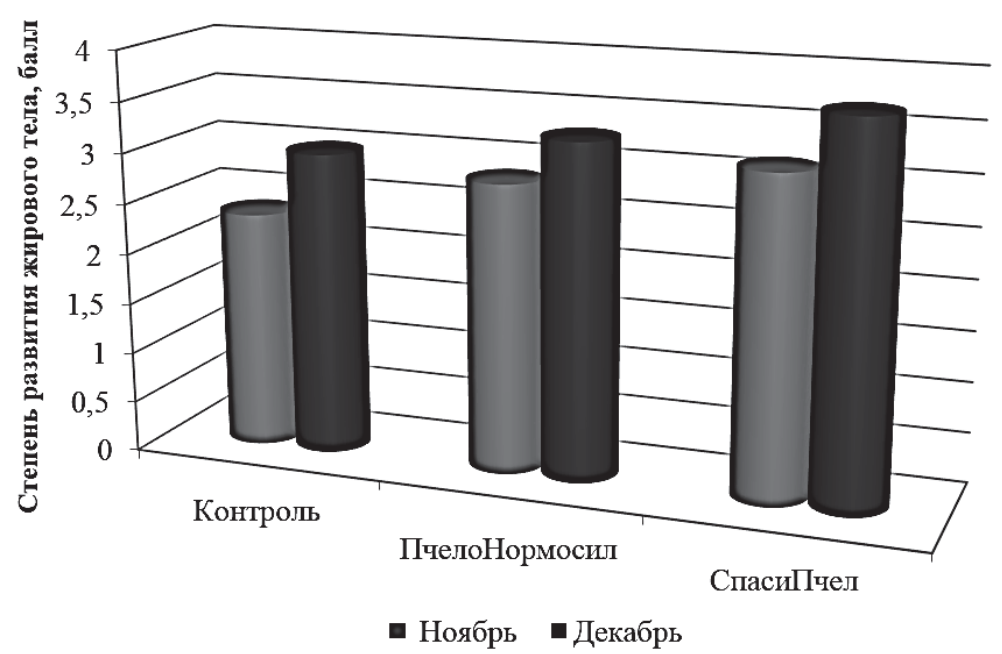

Рисунок 2

Степень развития жирового тела пчел при подкормке пробиотиками

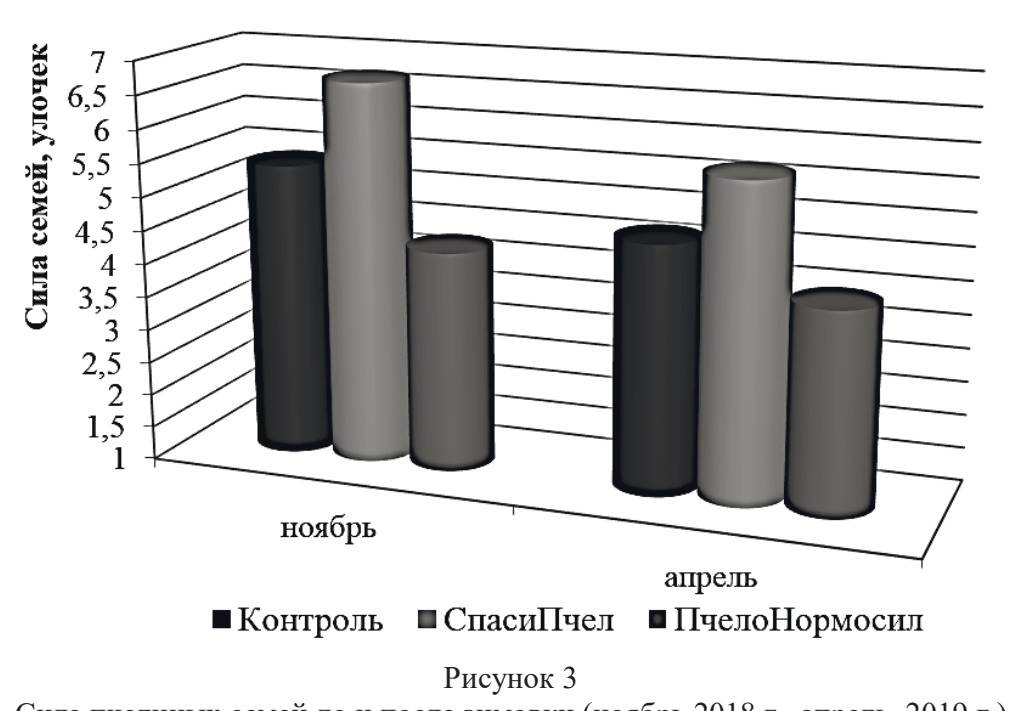

Таблица 1 Результаты зимовки пчелиных семей

\begin{tabular}{|c|c|c|c|c|}
\hline \multirow{2}{*}{\multicolumn{2}{|c|}{ Показатель }} & \multicolumn{3}{|c|}{ Группа пчелиных семей (вид подкормки) } \\
\hline & & контроль (СС) & 1 (СС + СпасиПчел) & 2 (СС + ПчелоНормосил) \\
\hline \multicolumn{2}{|l|}{ Масса подмора, г } & $73,0 \pm 6,9$ & $83,0 \pm 7,4$ & $52,0 \pm 4,6$ \\
\hline \multirow{2}{*}{ Расход корма, кг: } & на 1 семью пчел & $6,8 \pm 0,4$ & $6,7 \pm 0,1$ & $5,3 \pm 1,02$ \\
\hline & на 1 улочку пчел & $1,41 \pm 0,4$ & $1,1 \pm 0,1$ & $1,27 \pm 0,1$ \\
\hline \multicolumn{2}{|c|}{ Количество печатного расплода, сотни ячеек } & $61,3 \pm 9,9$ & $97,3 \pm 12,0$ & $75,7 \pm 9,8$ \\
\hline
\end{tabular}

Обсуждение результатов. Использование осенних подкормок в пчеловодстве направлено на пополнение кормовых запасов, необходимых пчелиной семье, чтобы благополучно пережить длительный безмедосборный период. Как правило, при этом сахарный сироп обогащают биологически активными веществами, способствующими оптимизации процессов жизнедеятель- ности пчел при подготовке к зимовке. В наших исследованиях для этой цели мы использовали пробиотические кормовые добавки нового поколения, разработанные ООО «НВП БашИнком» СпасиПчел и ПчелоНормосил. Первая из них содержит 2 штамма бактерий Bacillus subtilis, вторая - лактобактерии, бифидобактерии и пребиотик арабиногалактан (иммуномодулятор из хвои 
лиственницы сибирской). Результаты садковых опытов свидетельствуют об отсутствии токсического влияния этих кормовых добавок на организм пчел. В опытных группах, напротив, отмечено увеличение продолжительности жизни пчел, по сравнению с контролем, что согласуется с данными О.С Ларионовой [1] и El Khoury S. et al. [13]. Как показали результаты исследований, использование пробиотика СпасиПчел в осенней подкормке оказало положительное влияние на подготовку семей к зимовке. Рабочие пчелы, получавшие эту подкормку, накопили больше запасных питательных веществ в теле, о чем свидетельствует более высокий уровень развития жирового тела пчел - в среднем на 25,4 \% выше, чем у пчел контрольной группы. Это согласуется с результатами исследований О.С. Ларионовой с соавт., по данным которых осенние подкормки пчелиных семей сахарным сиропом с добавлением микробиологического препарата апиник повышают уровень белкового, липидного и углеводного обмена, увеличивая сырую и сухую массу тела, содержание в организме жира и азота [1]. Результаты зимовки пчелиных семей во многом зависят от количества молодых пчел, выращенных в конце лета, и общей силы пчелиной семьи. Сильные семьи с большим количеством молодых пчел хорошо переносят зимовку и весной быстрее набирают кондицию. В 1-й опытной группе, получавшей пробиотик СпасиПчел, пчелиные семьи перед постановкой в зимовник по силе опережали контрольную группу на 24 \%. Семьи 2-й опытной группы (ПчелоНормосил) по силе несколько уступали контролю. О положительном влиянии пробиотиков на основе Bacillus subtilis на силу семьи есть сведения в работах D.C. Sabaté et al. [21], и M.C. Audisio [8].

Весной после выставки из зимовника семьи 1-й опытной группы сохраняли преимущества по силе по сравнению с контролем и 2-й опытной группой. Это может быть связано с укреплением иммунного статуса организма пчел, снижением содержания условно-патогенной микрофлоры в кишечнике насекомых [4], уменьшением каловой нагрузки у пчел сильных семей [2].

При подкормке ПчелоНормосилом сила семей после выставки несколько уступала контролю. Однако необходимо отметить, что семьи 2-й опытной группы за безоблетный период меньше ослабли по сравнению с семьями контрольной группы. Если в контроле процент ослабления семей составлял 13,2 \%, то во 2-й опытной этот показатель составил лишь 7 \%. В этой группе отмечено и минимальное количество подмора. Максимальное его количество выявлено в гнездах 1-й опытной группы, что можно объяснить большим количеством пчел в этих семьях

Действие пробиотических добавок в составе осенних подкормок проявилось и в превосходстве пчелиных семей по количеству расплода в семье. По этому показателю пчелосемьи 1-й и 2-й опытных групп превосходили семьи контрольной группы на 58,7 \% и 23,5 \% соответственно.

Одним из важных показателей при оценке результатов зимовки является расход корма пчелиной семьей за зимний период. К концу зимовки, когда в семьях появляется расплод, потребление корма значительно возрастает. Это связано, прежде всего, с затратами энергии на обогрев гнезда. Чем сильнее семья, тем меньше энергии она тратит на поддержание оптимальной для расплода температуры воздуха в зоне расположения зимнего клуба пчела. В наших опытах расход корма на улочку пчел в более сильных семьях 1-й опытной группы был на $22 \%$ меньше контроля. Подобные результаты получены Е.А. Пшеничной, использовавшей в осенней подкормке препарат Эраконд в сочетании с пробиотиком Ветом 1.1 [6].

Таким образом, анализ полученных данных свидетельствует о том, что осенние подкормки пчелиных семей с добавлением пробиотика СпасиПчел на основе Bacillus subtilis способствуют увеличению продолжительность жизни рабочих пчел, накоплению резервных веществ в организме, сохранению силы семей и экономному расходу корма в период зимовки пчел. Кормовая добавка ПчелоНормосил на основе лакто- и бифидобактерий не оказала заметного влияния на показатели силы семей и расхода корма, но способствовала улучшению воспроизводительных качеств, о чем свидетельствует увеличение количества печатного расплода в семьях весной после выставки из зимовника по сравнению с контролем.

\section{Библиографический список}

1. Ларионова, О.С. Пути оптимизации гомеостаза и микроценоза пчел при содержании семей в ульях различного типа [Текст]: автореф. дис. ... докт. биол. наук / О.С. Ларионова. М., 2012.43 c.
2. Лойко, И.М. Эффективность использования продуктов пчеловодства для повышения энергии роста и естественных защитных сил организма телят [Текст] / И.М. Лойко, А. Г. Щепеткова // Современные технологии сельскохо- 
зяйственного производства. Материалы XV межд. науч.-практ. конф. (Гродно, 18 мая 2012 года). Гродно, 2012. Ч. 1. С. 391-393.

3. Маннапов, А.Г. Развитие и продуктивные показатели семей пчел при использовании пробиотического препарата Апиник [Текст] / А.Г. Маннапов, О. С. Ларионова // Зоотехния : теорет. и науч.-практ. журн. 2011. № 9. С. 29-30. ISSN 0235-2478.

4. Маннапов, А.Г. Влияние препарата апиник на иммунологические и микробиологические показатели пчел [Текст] / А.Г. Маннапов, Н.Д. Московская // Пчеловодство. 2019. № 4. С. 19.

5. Мишуковская, Г.С. Применение пробиотиков для повышения продуктивности темной лесной пчелы башкирской популяции [Текст]/ Г.С. Мишуковская // Темная лесная пчела Apis mellifera mellifera L. Республики Башкортостан. Уфа, 2015. С. 193-197.

6. Пшеничная, Е.А. Стимулирующие подкормки и зимовка пчел [Текст] / Е.А. Пшеничная // Пчеловодство. 2010. № 10. С.14-15.

7. Arredondo D., Castelli L., Porrini M.P., Garrido P.M., Eguaras M.J., Zunino P., Antúnez K. Lactobacillus kunkeei strains decreased the infection by honey bee pathogens Paenibacillus larvae and Nosema ceranae. Benef Microbes. 2018 Feb 27; 9 (2): 279-290. doi: 10.3920/BM2017.0075.

8. Audisio M.C. (2017) Gram-Positive Bacteria with Probiotic Potential for the Apis mellifera $\mathrm{L}$. Honey Bee: The Experience in the Northwest of Argentina. Probiotics \& Antimicro. Prot. 9, 22-31 doi:10.1007/s12602-016-9231-0.

9. Bleau N., Derome N., Giovenazzo P. (2019). The effects of probiotics on winter survival, spring development and gut microbiota of the honey bee (Apis mellifera) in Quebec, Canada. 46 ${ }^{\text {th }}$ APIMONDIA - International Apicultural Congress Congress - Montréal - Canada - Proceedings.

10. Bonilla-Rosso, German \& Engel, Philipp. (2018). Functional roles and metabolic niches in the honey bee gut microbiota. Current opinion in microbiology. 43. 69-76.10.1016/j.mib.2017.12.009.

11. Daisley B., Trinder M., Mcdowell T. et. al. (2017). Neonicotinoid-induced pathogen susceptibility is mitigated by Lactobacillus plantarum immune stimulation in a Drosophila melanogaster model. Scientific Reports. 7. 2703.10.1038/S41598017-02806-w.

12. Daisley B.A., Pitek A.P., Chmiel J.A. et al. (2019). Novel probiotic approach. ISME J. doi: 10.1038/s41396-019-0541-6.
13. El Khoury S., Rousseau A., Lecoeur A., Cheaib B., Bouslama S., Mercier P.-L., Demey V., Castex M., Giovenazzo P. and Derome N. (2018). Deleterious Interaction Between Honeybees (Apis mellifera) and its Microsporidian Intracellular Parasite Nosema ceranae Was Mitigated by Administrating Either Endogenous or Allochthonous Gut Microbiota Strains. Front. Ecol. Evol. 6:58. doi: 10.3389/fevo.2018.00058.

14. Fanciotti M.N., Tejerina M., BenítezAhrendts M.R. and Audisio M.C. (2018). Honey yield of different commercial apiaries treated with Lactobacillus salivarius A3iob, a new bee-probiotic strain. Beneficial Microbes, 9, 291-298.

15. Khaziakhmetov F.S., Khabirov A.F., Avzalov R.Kh., Tsapalova G.R., Rebezov M.B., Tagirov Kh.Kh., Giniyatullin Sh.Sh., Ishmuratov Kh.G., Mishukovskaya G.S., Gafarova F.M., Yessimbekov Zh.S. (2018) Effect of probiotics on calves, weaned pigs and lamb growth. Research Journal of Pharmaceutical, Biological and Chemical Sciences. T. 9. № 3. C. 866-870.

16. Khaziakhmetov F.S., Khabirov A.F., Avzalov R.Kh., Tsapalova G.R., Rebezov M.B., Tagirov Kh.Kh., Giniyatullin Sh.Sh., Ishmuratov Kh.G., Mishukovskaya G.S., Gafarova F.M., Esimbekov Zh.S. (2018) Valuable effect of using probiotics in poultry farming. Annual Research \& Review in Biology. T. 25. № 1. C. 1-7.

17. Lucie Kešnerová, Olivier Emery, Michaël Troilo, Joanito Liberti, Berra Erkosar and Philipp Engel (2019). Gut microbiota structure differs between honeybees in winter and summer, The ISME Journal, 10.1038/s41396-019-0568-8.

18. Maes P.W., Rodrigues P.A., Oliver R., Mott B.M., Anderson K.E. (2016) Diet-related gut bacterial dysbiosis correlates with impaired development, increased mortality and Nosema disease in the honeybee (Apis mellifera). Mol. Ecol. 25: 54395450 .

19. Maurizio A. Pollenernahrung und Lebensvorgange bei der Honigbiene (Apis mellifera) Landwiertsch. Jahrbschweis. 1954. 68. p. 115-182.

20. Raymann K., Moran N.A. (2018). The role of the gut microbiome in health and disease of adult honey bee workers. Curr Opin Insect Sci.; 26: 97104.

21. Sabate D.C., Cruz M.S., BenitezAhrendts M.R. and Audisio M.C. (2012). Beneficial effects of Bacillus subtilis subsp. subtilis Mori2, a honey-associated strain, on honeybee colony performance. Probiotics and Antimicrobial Proteins, 4, 39-46.

\section{Сведения об авторах}

1. Мищуковская Галина Сергеевна, доктор биологических наук, профессор кафедры физиологии, биохимии и кормления животных, ФГБОУ ВО Башкирский ГАУ, г. Уфа, ул. 50-летия Октября, 34, тел.: +7 (347) 228-07-73, e-mail: mishukovskaya@mail.ru. 
2. Гиниятуллин Марат Гиндуллинович, доктор сельскохозяйственных наук, профессор кафедры пчеловодства, частной зоотехнии и разведения животных, ФГБОУ ВО Башкирский ГАУ, 450001, г. Уфа, ул. 50-летия Октября, 34, тел.: +7 (347) 252-72-52, e-mail: 0803MARAT@mail.ru.

3. Шелехов Дмитрий Викторович, кандидат сельскохозяйственных наук, доцент кафедры пчеловодства, частной зоотехнии и разведения животных, ФГБОУ ВО Башкирский ГАУ, 450001, г. Уфа, ул. 50-летия Октября, 34, тел.: +7 (347) 252-72-52, e-mail: shelehov_d_v@mail.ru.

4. Смольникова Елена Алексеевна, кандидат сельскохозяйственных наук, ст. преподаватель кафедры физиологии, биохимии и кормления животных, ФГБОУ ВО Башкирский ГАУ, г. Уфа, ул. 50-летия Октября, 34, тел.: +7 (347) 228-07-73, e-mail: selenaa64@mail.ru.

5. Науразбаева Айгуль Ильдаровна, магистрант кафедры физиологии, биохимии и кормления животных, ФГБОУ ВО Башкирский ГАУ, г. Уфа, ул. 50-летия Октября, 34, тел.: +7 (347) 228-07-73, e-mail: naurazbaeva.aigul@mail.ru.

Для поддержания здоровья семьи и восполнения дефицита корма используют осенние подкормки, содержащие сахарный сироп в комбинации с различными биологически активными добавками для профилактики болезней пчел. Ужесточение требований к качеству продукции пчеловодства, её экологической чистоте ограничивает возможность применения для этой цели химиотерапевтических средств. В качестве альтернативы рассматривается возможность использования микробиологических препаратов, созданных на основе нормальной микрофлоры кишечника пчел для стимуляции иммунной системы. В статье приводятся данные о влиянии осенней подкормки пчелиных семей сахарным сиропом, обогащенным пробиотическими кормовыми добавками СпасиПчел (Bacillus subtilis) и ПчелоНормосил (лакто- и бифидобактерии). В садковых опытах при подкормке пробиотиками продолжительность жизни пчел достоверно превышала контрольное значение - в 1,2 раза (СпасиПчел) и 1,14 раза (ПчелоНормосил). Обогащение сахарного сиропа кормовой добавкой СпасиПчел во время осенней подкормки способ- ствовало лучшей подготовке семей пчел к зимовке. По силе семей перед постановкой в зимовник они превосходили контроль на $24 \%$, по уровню развития жирового тела рабочих пчел на $25,4 \%$. Весной после выставки из зимовника они сохраняли превосходство по силе на $21,3 \%$, количеству печатного расплода - на 58,7 \%, расход корма за период зимовки на одну улочку в этих семьях был меньше на $22 \%$. Кормовая добавка ПчелоНормосил на основе лакто- и бифидобактерий не оказала заметного влияния на показатель силы семей и расход корма, но способствовала улучшению воспроизводительных качеств, о чем свидетельствует увеличение количества печатного расплода в семьях весной после выставки из зимовника на 23,5 \% по сравнению с контролем. Результаты исследований подтверждают возможность использования пробиотических кормовых добавок в осенней подкормке пчел. Требуются дальнейшие исследования по изысканию оптимального состава пробиотиков, способствующих лучшей сохранности пчелиных семей за период зимовки.

G. Mishukovskaya, M. Giniyatullin, D. Shelekhov, E. Smolnikova, A. Naurazbaeva

\section{EFFECTIVENESS OF PROBIOTIC FEED SUPPLEMENT FOR AUTUMN FEEDING OF HONEY BEES}

\section{Key words: honeybees; autumn feeding; overwintering; probiotics; strength of families; sealed brood.}

\section{Authors' personal details}

1. Mishukovskaya Galina, Doctor of Biology, Professor of the Department of Physiology, Biochemistry and Animal Feeding, Federal State Budgetary Educational Institution of Higher Education «Bashkir State Agrarian University», 450001, Ufa, 50-letiya Oktyabrya St., 34, phone: +7 (347) 228-07-73, e-mail: mishukovskaya@mail.ru.

2. Giniyatullin Marat, Doctor of Agriculture, Professor of the Department of Beekeeping, Private Animal Husbandry and Animal Breeding, Federal State Budgetary Educational Institution of Higher Education «Bashkir State Agrarian University», 450001, Ufa, 50-letiya Oktyabrya St., 34, phone: +7 (347) 252-72-52, e-mail: 0803MARAT@mail.ru

3. Shelekhov Dmitriy, Candidate of Agricultural Sciences, Associate Professor of the Department of beekeeping, Private Animal Husbandry and Animal Breeding, Federal State Budgetary Educational Institution of Higher Education «Bashkir State Agrarian University», 450001, Ufa, 50-letiya Oktyabrya St., 34, phone: +7 (347) 252-72-52, e-mail: shelehov_d_v@mail.ru. 
4. Smolnikova Elena, Candidate of Agricultural Sciences, Senior Lecturer of the Department of Physiology, Biochemistry and Animal Feeding, Federal State Budgetary Educational Institution of Higher Education «Bashkir State Agrarian University», 450001, Ufa, 50-letiya Oktyabrya St., 34, phone: +7 (347) 228-0773, e-mail: selenaa64@mail.ru.

5. Naurazbaeva Aigul, master's degree student of the Department of Physiology, Biochemistry And Animal Feeding, Federal State Budgetary Educational Institution of Higher Education «Bashkir State Agrarian University», 450001, Ufa, 50-letiya Oktyabrya St., 34, phone: +7 (347) 228-07-73, e-mail: naurazbaeva.aigul @mail.ru.

In autumn honey bees are provided with feeds containing sugar syrup in combination with various biologically active disease prevention supplements to maintain the health of the honey bee family and make up for the lack of feed. Since the requirements for the quality of bee products and their environmental cleanliness have become even more rigid the use of chemotherapeutic agents is limited for this purpose. Microbiological products may be alternatively applied; the products are based on the normal intestinal microflora of bees to stimulate the immune system. The paper discusses the effect of autumn feeding of bee families with sugar syrup enriched with probiotic feed supplements «SpasiPchel» (Bacillus subtilis) and «PcheloNormosil» (lacto- and bifidobacteria). The cage-type experiments showed that life expectancy of honey bees significantly exceeded the control value when they were fed probiotic supplements (1,2 times when added «SpasiPchel» and 1,14 times when added «PcheloNormosil»). Adding the feed supplement «SpasiPchel» to the sugar syrup in autumn feeding of honey bees was a more effective way to prepare bee families for overwintering. Before putting the families in in-door wintering sheds the family strength indices exceeded the control figures by $24 \%$, the fat body growth indices of working bees exceeded the control figures by $25,4 \%$. In spring when brought out from the wintering sheds the families remained $21,3 \%$ stronger, the number of sealed brood was 58,7 \% larger, the feed consumption for the winter period per seam of bees between two combs was $22 \%$ lower. The feed supplement «PcheloNormosil» based on lactic and bifidobacteria did not have a noticeable effect on the strength of families and feed consumption, but improved their reproductive properties. In spring the sealed brood in the families was $23,5 \%$ higher than in the control. The study results confirm that probiotic feed supplements can be effectively used in the autumn feeding of honey bees. Further studies are required to find the optimal composition of probiotics that foster preservation of bee families during the wintering period.

(c) Мишуковская Г.С., Гиниятуллин М.Г., Шелехов Д.В., Смольникова Е.А., Науразбаева А.И.

УДК 636.22/.28.084.413

DOI: $10.31563 / 1684-7628-2020-53-1-106-110$

М.Т. Сабитов, А.Р. Фархутдинова, И.М. Фархутдинов, М.Г. Маликова

\section{ЭКОНОМИЧЕСКАЯ ЭФФЕКТИВНОСТЬ СКАРМЛИВАНИЯ КОМПЛЕКСНОЙ МИНЕРАЛЬНО-ВИТАМИННОЙ КОРМОВОЙ ДОБАВКИ «НАДЕЖДА» В СОСТАВЕ РАЦИОНА ТЕЛЯТ}

\section{Ключевые слова: кормовая добавка; цеолит природный; сапропель; молодняк крупного рога- того скота; валовый прирост; себестоимость; прибыль; рентабельность выращивания.}

Введение. Минеральные добавки играют важную роль в организации полноценного питания, повышении продуктивности и эффективности отрасли животноводства в целом $[6,7,11]$. Для балансирования рационов кормления по минеральным веществам в последние годы на практике применяются различные нетрадиционные местные природные добавки с богатым минеральным составом, такие как бентонит, сапропель, цеолит, магнезит, известняк [7, 2].

Использование нетрадиционных минеральных подкормок в рационах животных экономи- чески выгодно, так как многие из них по физико-химическим свойствам являются уникальными.

В нашем случае мы отдаем предпочтение природному цеолиту Башкирского происхождения, механизм действия которых в организме животных представляет большой интерес: в результате обменных процессов высвобождаются макро- и микроэлементы, являющиеся дополнительным источником минеральных веществ в рационе, находясь в более доступной форме для организма животных. 